\title{
The Outbreak of COVID-19 and Islamic Stock Market Responses in Indonesia
}

\author{
Rianda Rizky Permata $^{1 *}$; Budi Purwanto ${ }^{2}$; Wita Juwita Ermawati ${ }^{3}$ \\ ${ }^{1,2,3}$ Department of Magister Management, Faculty of Economics and Management, IPB University \\ J1. Raya Dramaga, Kampus IPB Dramaga Bogor 16680, Indonesia \\ 1'permatarianda@apps.ipb.ac.id; ${ }^{2}$ budipurwanto@apps.ipb.ac.id; ${ }^{3}$ witaman@apps.ipb.ac.id
}

Received: $28^{\text {th }}$ February 2021/ Revised: $05^{\text {th }}$ April 2021/ Accepted: $12^{\text {th }}$ April 2021

How to Cite: Permata, R. R., Purwanto, B., \& Ermawati, W. J. (2021). The outbreak of COVID-19 and Islamic stock market responses in Indonesia. The Winners, 22(2), 105-112. https://doi.org/10.21512/tw.v22i2.7104

\begin{abstract}
The research intended to analyze the overreaction phenomenon in Islamic stocks due to COVID-19 as well as the influencing factors by utilizing different test methods and cross-sectional regression. The research employed data on the daily stock prices from August $9^{\text {th }}, 2019$ to October $26^{\text {th }}$, 2020 on the Jakarta Islamic Index (JII) and the stocks utilized during the period of events. The sample of the research utilized seven events related to COVID-19. The findings reveals that the announcement of COVID-19 transmission and lockdown (Event 2) causes overreaction in winner stocks. Meanwhile, the overreaction phenomenon of loser stock is due to the announcement of the United States fiscal stimulus (Event 5) and the announcement of the PSBB (Event 6). Furthermore, the new normal announcement event (Event 7) triggers overreaction in the winner and loser stocks. The results indicate that Islamic stocks continue to have several transactions which are prohibited by the Fatwa DSN MUI in the short term. In this case, the variables that impact the overreaction phenomenon are shown to be substantially and negatively linked to leverage and market capitalization, while trading volume significantly influences and has a positive correlation with the overreaction phenomenon.
\end{abstract}

Keywords: COVID-19, Islamic stock market, stock market responses

\section{INTRODUCTION}

According to the World Bank (2020), the COVID-19 pandemic is an unexpected event that has a major impact on all sectors including the economic sector. Since the effect was huge and widespread, it caused a recession that was much worse than the global financial crisis of 2008. The spread of COVID-19 has had a negative effect on global commodity markets, as crude oil prices have decreased (Hassan \& Gavilanes, 2021). World stock market indices including the NASDAQ and Nikkei, which are the stock market reference indexes, also experienced increased volatility as an indication that investors are responding significantly to COVID-19. As a result of COVID-19, overall stock market indices across the globe experienced declining extreme price (bearish) (Ibrahim, Kamaludin, \& Sundarasen, 2020; Siddiqui, Ahmed, \& Naushad, 2020). The stock markets of countries affected by COVID-19 have negative abnormal returns due to investors' pessimism about market conditions, causing the stock market to undergo the phenomenon of an overreaction (Liu et al., 2020). In this case, Indonesia has been one of the countries affected by COVID-19, especially since the announcement of the first case confirmation occurred on March $2^{\text {nd }}, 2020$. The Indonesian capital market was also affected by COVID-19 as shown by the Composite Stock Price Index (CSPI) which touched the lowest level of $3.937,517$ on March $24^{\text {th }}, 2020$, in the past seven years. The price movement continues to change during the COVID-19 pandemic.

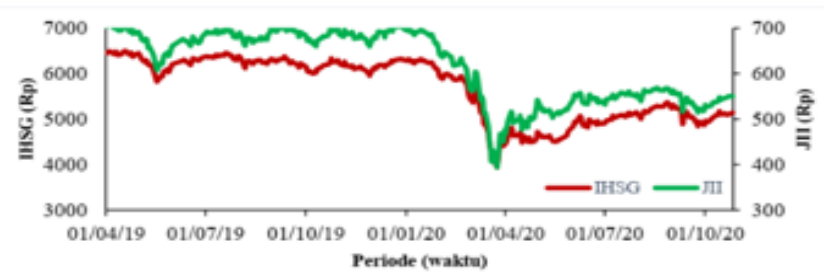

Figure 1 Fluctuation of CSPI and Jakarta Islamic Index (JII) before and after COVID-19 pandemic

Source: Yahoo Finance and IDX (2020) (data processed) 
Figure 1 shows that the stock price movement of companies in the Indonesian capital market reflected by CSPI has significant volatility. Before the outbreak of COVID-19 stock prices was relatively stable. On the contrary, after the outbreak, stock indices plummet and quickly surge in a short time.

The condition of the Indonesian capital market has experienced a deep decline in stock prices, including Islamic stocks. The decline in stock prices and the high volatility that occurs in the Islamic stock market can cause an overreaction phenomenon. Overreaction appears due to fraudulent information that causes misleading information and tends to be a tadlis violation (transparency of information and prohibition of misleading information) (Mujadiddah, Achsani \& Irfany, 2020). Sharia stocks are the ones whose operations are regulated in accordance with the sharia principles. Sharia stock operational arrangements are listed in the Fatwa DSN MUI Number 80 of 2011 which explains that the prohibition of behavior containing elements of maisir, dharar, usury, immorality and tyranny, gharar, ghabn, risywah, talaqqi al-rukban, tadlis, tanajusy/najsy, ghisysy, bai 'al-ma' dum, taghir, and iktikhar. The implication of this prohibition regarding these elements prevents the practice of insider trading, misleading information, and front running (Mujadiddah et al., 2020). The implementation of sharia principles should be able to make the Islamic stock market more efficient than the common stock market (Yan, 2020). The enforced regulation can encourage investors to behave in accordance with efficient market mechanisms. However, the practice of Islamic stock trading that currently occurs is still incompatible with the ideal Islamic stock market. This is also supported by Tanjung and Siregar (2018) reporting that the returns on shares listed in JII fluctuate significantly, resulting in significant gains and losses in a single day for investors. Fatima, Rashid and Khan (2019) also find that Islamic stock returns show a significant reaction to negative events. Furthermore, Islamic stock inefficiency is also discovered by Mujadiddah et al. (2020) who conduct research on the short-term overreaction phenomenon to certain events in stocks listed on JII. The results of these studies indicate that the bombing incident in Surabaya results in excessive stock reactions.

The research also examines the influencing factors on the overreaction phenomenon in these events. According to the previous studies, the phenomenon of stock market overreaction to an event can be examined by utilizing an event study approach. Boubaker, Farag, and Nguyen (2015) find that there is a phenomenon of overreaction in the Egyptian stock market by testing the daily abnormal return of stocks during the 100-day trading period before and after the event. It seems that research on the overreaction phenomenon to Islamic stocks is still limited despite the development of the Islamic stock market as indicated by the rise in companies listed in Islamic stocks and the existence of Islamic stock indices.
Apart from the implementation of the applicable Fatwa DSN MUI, there is still a possibility of a reaction to the inefficiency of the Islamic stock market toward unfortunate events, especially in the current COVID19-related event sequence. Therefore, the research is conducted to investigate how Islamic stocks listed on JII responded to COVID-19 could contribute to the phenomenon of overreaction. In addition, the research examines the reaction of Islamic stocks and analyzes the influencing factors regarding the overreaction phenomenon. It is due to the fact that this research is pivotal to be carried out since there are still limited sources regarding the overreaction phenomenon.

\section{METHODS}

The data employed in the research are daily stock prices during the period August 9 ${ }^{\text {th }}, 2019$ to October $26^{\text {th }}, 2020$ on the Jakarta Islamic Index (JII) and the stocks utilized during the period of events. Seven specific events are followed by price reversal and return reversal (De Bondt \& Thaler, 1985). The determination of the observation period in the research is based on research by Mujadiddah et al. (2020) and Boubaker et al. (2015). The period used for adjustments to determine the reaction of the Islamic stock market consists of three periods: 1) the estimation period, 2) the event period and 3 ) the test period. The estimation period is 100 trading days before the event $(\mathrm{t}-100)$ to determine the overreaction hypothesis; the event period is a day when the event occurs $(t=0)$; while the test period is 100 trading days after the event $(t+100)$ to determine the factors that influence the overreaction phenomenon.

There are seven samples of COVID-19 events selected, which entail: reporting the first case by the Chinese government to WHO (Event 1); the announcement of transmission of COVID-19 and Lockdown by the Chinese government (Event 2); the announcement of COVID-19 first case confirmation in Indonesia (Event 3); the announcement of COVID-19 as a Pandemic (Event 4); the announcement of the economic stimulus policy of the United States (Event $5)$; the announcement of the policy of large-scale social restrictions (Event 6); and the announcement of the implementation of New Normal (Event 7). Table 1 provides detailed events and periods in the research.

The steps of the analysis determination of the winner and loser stock categories are conducted according to the research by Boubaker et al. (2015), Farag and Cressy (2010) and Musnadi, Faisal and Majid (2018) by estimating abnormal returns during the 100-day testing period after the event.

The first step is to calculate the daily returns value. The formula of daily return is the first difference in the natural logarithm (Ln) of the ke-i stock closing price between two trading days (Boubaker et al., 2015). The return variables used are stock returns (Rit) and market returns (Rmt). Price (Pit) is defined as the closing price of each stock in period t (Lobe \& Rieks, 
Table 1 List of Events and Periods Included in the Study

\begin{tabular}{ccccc}
\hline No & Current Events & Estimation period t-100 & Event period t $=\mathbf{0}$ & Test period t $+\mathbf{1 0 0}$ \\
\hline 1. & Event 1 & $09 / 08 / 2019$ & $2 / 01 / 2020$ & $2 / 06 / 2020$ \\
2. & Event 2 & $27 / 08 / 2019$ & $20 / 01 / 2020$ & $18 / 06 / 2020$ \\
3. & Event 3 & $8 / 10 / 2019$ & $02 / 03 / 2020$ & $30 / 07 / 2020$ \\
4. & Event 4 & $18 / 10 / 2019$ & $12 / 03 / 2020$ & $12 / 08 / 2020$ \\
5. & Event 5 & $31 / 10 / 2019$ & $25 / 03 / 2020$ & $28 / 08 / 2020$ \\
6. & Event 6 & $11 / 11 / 2019$ & $06 / 04 / 2020$ & $08 / 09 / 2020$ \\
7. & Event 7 & $2 / 01 / 2020$ & $2 / 06 / 2020$ & $26 / 10 / 2020$ \\
\hline
\end{tabular}

2011):

Rit $=$ Ln Pit - Ln Pit -1

$\mathrm{Rm} t=\operatorname{Ln} P m t-\operatorname{Ln} P m t-1$

Furthermore, it is important to calculate the abnormal return. Abnormal return is defined by using the market adjusted model, whereas the expected return is the value of the market return index in the same period (Musnadi et al., 2018).

$\mathrm{ARit}=$ Rit $-\mathrm{Rmt}$

After getting the abnormal return value, the next step is to calculate the Cumulative Abnormal Return (CAR). Cumulative abnormal return is the sum of the abnormal return of a stock during the estimated research period. The research accumulates abnorma returns into two periods: 1) before the event occurs to determine the category of the stock portfolio and 2) after the event occurs to examine the effect of the overreaction phenomenon (Mujadiddah et al., 2020). The highest CAR value will be the winner stock category and the lowest will be the loser stock category.

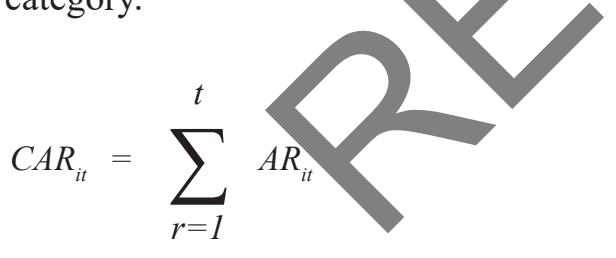

After determining the stock portfolio's category, the next step is testing the hypothesis of stock overreaction phenomenon. The test uses the following formula to compare the average abnormal return (AAR) value of Islamic stocks on each winner and loser portfolio between the periods before and after the case.

$A A R_{t}=\frac{\sum_{i=1}^{I} A R_{i t}}{I}$

Moreover, it is considered necessary to calculate the cumulative average abnormal return (CAAR), which is used to determine the information leakage (leak) indicator obtained from the CAAR values three days before the event occurred (Boubaker et al., 2015).

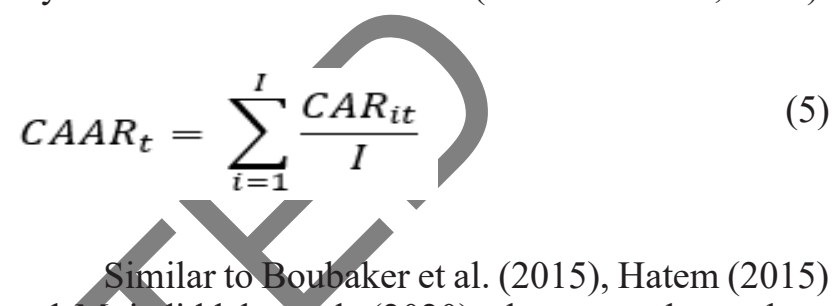
and Mujadiddah et al. (2020), the research employs a cross sectional regression method to determine the influencing factors on the overreaction phenomenon in Islamic stocks in Indonesia. The research model can e seen in the formula:

$C A R i=\alpha+\beta 1 A R i+\beta 2$ Leaki $+\beta 3$ Ln_Mcap $i+$ $\beta 4 L T V i+\beta 5$ Levi $+e i$

where:

CARi $=$ cumulative abnormal return $\mathrm{i}$ stock, with the value of $\mathrm{CAR}_{\mathrm{i}}=$ $\underline{\sum_{t=1}^{100} \text { CAARit }}$ 10

(Boubaker et al., 2015)

$A R i_{(0)}=$ abnormal return of I stock in the occurrence events

Leak $_{i}=$ information leakage on I stock in the occurrence events

Ln_Mcapi = natural logarithm of I stock market capitalization at $\mathrm{t}-127$

LTVi $=$ trading volume of I stock with a value of TVt / TVt-1 (Boubaker et al., 2015)

Lev $=$ company leverage with the value of long term debt / total equity (Hatem, 2015)

$\alpha=$ intercept

$\beta 1, \beta 2, \beta 3,=$ estimated parameter $\beta 4, \beta 5$

$e_{i} \quad=\quad$ residual 


\section{RESULTS AND DISCUSSIONS}

The research employs seven events related to the COVID-19 pandemic. The period used in the research is 201 days divided into three parts. First, the 100 days prior to the event are used to form a winner-loser stock portfolio. Second, one day is used for the day when the event occurred. Lastly, 100 days after the event occurred are used to examine the influencing factors to the overreaction phenomenon. In the analysis, the estimation period is 100 days before the event, and the stock portfolio is formed in 10 days. As a result, each event has 10 stocks that are included in both the winner's and loser's portfolios.

According to Mujadiddah et al. (2020), the value of the average abnormal return (AAR) is used to test the overreaction hypothesis in this analysis. The test period used is the AAR value before and after the event occurred for each type of portfolio in each event. The Islamic stock overreaction will occur if there is a disparity between these events. In addition, the test analysis tool is a paired two-sample difference test for the parametric data, while Wilcoxon Signed Rank test is for the non-parametric data. The results of the significance of the overreaction test can be seen in Table 2.

The overreaction hypothesis is tested on seven significant events related to COVID-19. It is found that four significant events have overreaction. Since the stock price obtained by investors reflects the lack of available information and market inefficiency (Fama, 1970), this means that the Islamic stock market in Indonesia is not quite stable. On the other hand, Fatwa DSN MUI Number 40 of 2003 states that the price of traded shares must be fair. The price must represent the value of actual valuation of the issuer, economic, political, and other conditions. Therefore, the results of the overreaction hypothesis testing on the Islamic stock market towards COVID-19 are not in accordance with the theory which states that Islamic stocks have more efficiency and avoid efficient market anomalies. Stable Islamic stock market conditions should be able to explain what is defined as disclosure in the stock market. The information available can be reflected in the stock price since investors fully understand the origin of price fluctuations from existing information, both from a fundamental and technological viewpoint. Market efficiency also creates free market conditions, in which there is no intervention from certain parties that affects the stock price. The short term testing indicates that the COVID-19 pandemic brings about overreaction causing Islamic stock market not to achieve its ideal conditions. As a consequence, it is conceivable that transactions which are illegal under Islamic law may still be found on Islamic stocks. Mujadiddah et al. (2020) discover major information leakage as well as a correlation between information and stock prices. This may occur as a result of the dissemination of misleading information. In fact, the misleading information is a transaction that provides incorrect information so that it affects stock prices in order to gain a profit above normal profit. This transaction is categorized as tadlis which is prohibited in the fatwa DSN MUI Number 80 of 2011. The violation of the Fatwa is proven in the short term. Therefore, further research regarding the influencing on the overreaction of sharia stocks against COVID-19 needs to be conducted in order to discover the transaetions violations.

The test aims to determine the factors that significantly influence the overreaction phenomenon in the two occurrence events. Before the testing is conducted, certain assumption tests need to be fulfilled, such as normality, heterocedasticity, multicollinearity, and autocorrelation tests. All the assumptions in the research show a significant fulfillment. The test results using the cross-sectional regression model are shown in Table 3.

Table 2 T-Test Results for All Samples

\begin{tabular}{|c|c|c|c|c|}
\hline \multirow{2}{*}{ No } & \multirow{2}{*}{ Sample Events } & \multirow{2}{*}{ Event Description } & \multicolumn{2}{|c|}{ P Value } \\
\hline & & & Winner & Loser \\
\hline 1. & Event 1 & $\begin{array}{l}\text { Announcement of the first case of COVID-19 confirmation to } \\
\text { WHO }\end{array}$ & 0,155 & 0,376 \\
\hline 2. & Event 2 & $\begin{array}{l}\text { Announcement of the COVID-19 and lockdown transmission by } \\
\text { the Chinese government }\end{array}$ & $0,02723 *$ & 0,1197 \\
\hline 3. & Event 3 & $\begin{array}{l}\text { Announcement of the first case of COVID-19 confirmation in } \\
\text { Indonesia. }\end{array}$ & 0,3743 & 0,6084 \\
\hline 4. & Event 4 & Announcement of COVID-19 as a pandemic & 0,6761 & 0,1372 \\
\hline 5. & Event 5 & Announcement of the United States economic stimulus policy & 0,4608 & $0,09643 * *$ \\
\hline 6. & Event 6 & Announcement of large-scale social distancing (PSBB) policies & 0,2685 & $0,0000388^{*}$ \\
\hline 7. & Event 7 & Announcement of the New Normal implementation & $0,00002556^{*}$ & $1,941 \mathrm{e}-12 *$ \\
\hline
\end{tabular}

Source: Yahoo Finance and IDX (2020) (data processed)

Description: the values in parentheses are the p-values $* *$, and $*$ are significant at the levels of $0,01,0,05$, and 0,1 
Table 3 Estimated Results of CSR for Winner Stock Groups at Event 2

\begin{tabular}{lc}
\hline \multicolumn{1}{c}{ Independent Variable } & Dependent Variable: CARi \\
\hline $\mathrm{C}$ & $-2,069$ \\
& $(0,114)$ \\
$\mathrm{AR}$ & 3,261 \\
& $(0,249)$ \\
Leak & $-3,101$ \\
& $(0,506)$ \\
Ln_MCap & $0,071^{*}$ \\
& $(0,096)$ \\
LTV & $-0,151^{*}$ \\
& $(0,051)$ \\
Lev & $-0,089^{*}$ \\
& $(0,058)$ \\
R-squared & 0,865 \\
Adjusted R-squared & 0,695 \\
Prob (F-statistic) & $0,069^{*}$ \\
\hline
\end{tabular}

Source: Yahoo Finance and IDX (2020) (data processed) Description: the values in parentheses are the p-values * are significant at the levels of $0,01,0,05$, and 0,1

Table 3 shows the estimation results on the announcement of the COVID-19 transmission and lockdown (Event 2) utilizing the multiple regression method of cross section data. This estimation explores the factors that affect overreaction on stocks in the winner's portfolio at the time of the COYID-19 event. Some of the statistical tests can be seen in the Table 3 , including the value of R-squared $\left(\mathrm{R}^{2}\right)$, F-statistic, and t-statistic. Statistical analysis of the COVID-19 transmission announcement indicates an $R^{2}$ value of 0,865 . This value shows that $86,5 \%$ of the variance in the cumulative abnormal return (CAR) dependent variable can be explained by factors in the model, while the remaining is explained by other factors outside the model. The probability F-statistic value in the winner stock of sharia portfolio model shows a value of 0,069 less than the real level of 0,10 . This means that the independent variables in altogether can explain the overreaction phenomenon. A high value of $\mathrm{R}^{2}$ and a significant statistical $\mathrm{F}$ result may indicate that the factors in the model affect the overreaction phenomenon. This can be proven through the t-statistic value which is utilized to explain the relationship between the independent variables to the overreaction phenomenon explained by the cumulative abnormal return (CAR) variable. The model specification and the coefficient of each variable can be written in the formula:

CARi $=-2,069+3,261$ ARi $(0)-3,101$ Leaki + 0,071Ln_Mcapi-0,151LTVi-0,089Levi+ei

According to the findings in Table 3, the first variable that affects the overreaction phenomenon in the announcement of the COVID-19 transmission and lockdown is trading volume (LTV). This variable is obtained from the comparison of the volume of stock trading in the occurrence event $(t=0)$ with the volume of stock trading the day before (t-1). This variable describes how changes in stock trading volume influence the phenomenon of sharia's stock overreaction, which is a winner portfolio. LTV has a significant negative correlation to this phenomenon with a coefficient value of $-0,151$. It means that the smaller stock trading volume in the occurrence event compared to the previous day's trading volume causes more vulnerable stock to the overreaction phenomenon. It is in accordance with the research hypothesis that there is an overreaction significant and inversely proportional relationship between trading volume and the overreaction phenomenon. These results are in line with the research by Ali, Ahmad, and Anusakumar (2012) and Sohail, Rehman, and Javid (2017) pointing out that stocks that have a smaller trading volume are increasingly prone to overreaction.

The second variable that affects the overreaction phenomenon is Leverage (Lev). This variable is the ratio between long-term debt and the company's total equity at the occurrence event. This variable is negatively related and significantly influences the overreaction phenomenon with a coefficient value of $-0,089$. This means that the greater the company's debt ratio, the more vulnerable the company's shares to the overreaction phenomenon. The findings of the research estimation are in accordance with the research hypothesis and in line with the research by Fauzi and Wahyudi (2016).

A company which has an increase in the debt ratio will lead to a bankruptcy when the company is unable to pay its obligations. Therefore, it is believed that the increase of company's long-term debt will be responded excessively by investors. Market capitalization (MCap) is the last variable that affects the overreaction phenomenon during the announcement of the COVID-19 transmission and lockdown (Event 2 ). This variable delineates the size of a company obtained from the multiplication value of the stock price and the number of circulation stocks of the company. Market capitalization variables can explain the phenomenon of Islamic stock overreaction which is a winner of portfolio during the COVID-19 event. This variable has a significant positive correlation to the dependent variable with a coefficient value of 0,071 . The finding interprets that the greater market capitalization will bring about a more vulnerable overreaction phenomenon. This result is in line with research by Lerskullawat and Ungphakorn (2019) and Fauzi and Wahyudi (2016) who discover that during the crisis occurs, the stock market reacts more to the large value of the stock market capitalization.

It can be said that this result is the opposite of the research hypothesis which states that market capitalization is negatively related to the overreaction phenomenon. The research hypothesis applies when market conditions are not undergoing a crisis. Thus 
smaller value of market capitalization will lead the society to become more susceptible to overreaction. The COVID-19 event is a crisis that differs from ordinary conditions, even more severe than in the previous global economic crisis, thus triggering the actions of investors who are pessimistic as they do not want to involve in a big risks in placing their investment funds. In this case, investors tend to choose companies with large market capitalizations, it is owing to the fact that the large company stocks are more liquid during the COVID-19 pandemic crisis. Therefore, the research results differ from the research hypothesis due to the difference of the characteristics of the events and the sample of Islamic stocks utilizing the companies with the largest capitalization in the last year. The regression test results for other variables, one of which is abnormal return, show that there is no significant correlation with the dependent variable, namely cumulative abnormal return (CAR). The results shows that the significance of this variable is more than the real level of 0,249 . This result addresses that the overreaction phenomenon that occurs during the COVID-19 announcement is not influenced by abnormal returns when the event occurs $(t=0)$. Furthermore, this result is in contrast with the hypothesis, which states that CAR variable has a substantial correlation. It can be summarized that, during the COVID-19 overreaction phenomenon, investors' decisions are not influenced by the returns obtained, but other factors that influence overreaction, namely: 1) market capitalization, 2) trading volume, and 3) leverage, as well as other factors outside the model.

Moreover, information leakage is another component in the model that is predicted in affecting the overreaction phenomenon. The significance level for this variable yields a value of 0,51 , which is $10 \%$ higher than the actual level used. These findings suggest that information leakage variable has no effect on the overreacting phenomenon of winner stocks of sharia portfolio during COVID-19 transmission and lockdown announcements (Event 2). The absence of the leakage effect is different from the research hypothesis. This difference probably occurs since investors have not realized about information regarding unpredictable events such as COVID-19, hence information leakage cannot be used as a consideration for analyzing investors' decisions. This is in accordance with the research by Mujadiddah et al. (2020) which describes that the leakage of information significantly affects the overreaction of sharia stocks in a predictable event, i.e., the election of Donald Trump as the US President. On the contrary, in the previous unpredictable events of Surabaya bombing, the information leakage variable did not affect the overreaction phenomenon. Therefore, in the sharia stock overreaction phenomenon on the COVID-19 event, there is no information leakage in light of sharia principle transactions violation which is called misleading information.

The findings reveal that several variables have no effect on the overreaction phenomenon and are inconsistent with the research hypothesis. This contradicts with the previous research by Boubaker et al. (2015), who identified that overreaction is affected by a major leakage factor. This divergence is due to the characteristics of the incidents under investigation, which result in discrepancies in investor analysis while performing Islamic stock transactions in Indonesia.

Sharia stocks are one of the long-term investment instruments yet allowed to conduct shortterm transactions. Fatwa DSN MUI Number 80 Year 2011 regulates this with a special provision which states that investors can sell securities (stocks) after the sale, and purchase agreement is valid even though the administrative settlement is carried out at a later date.

This statement is in accordance with the qadh hukmi principle, which is the use of assets by the buyer in the form of asset ownership documents in both electronic and non-electronic records. This is adjusted to stock transactions in which ownership of stocks has become the buyer's right since the sale and purchase agreement is valid even though it is not administratively valid. Stock buyers can immediately sell their stocks, which is lawful in sharia. This can lead to speculative transactions, i.e. buying and selling with the intention of obtaining high profits and avoiding large losses.

Sharia stocks are guided by Islamic law, whose principles and implementation are in accordance with the provisions of the Fatwa DSN MUI. There are two fatwa regulating sharia stocks, namely: 1) the Fatwa MUI DSN Number 40 of 2003 concerning the capital market and general guidelines for the application of sharia principles in the capital market; and 2) the Fatwa DSN MUI Number 80 of 2011 concerning the application of sharia principles in the equity trading mechanism of the stock exchange regular market. Meanwhile, the Islamic stock market is expected to become more efficient as sharia principles, which emphasize fairness and honesty in stock transactions.

According to the research results, it appears that there is a short-term overreaction of Islamic stocks in the COVID-19 event. This indicates that Islamic stocks are less efficient in the brief period, enabling investors to engage in speculative and haram transactions in response to stock price fluctuations triggered by COVID-19, with the intention of making profit beyond normal limits. This illustrates that Islamic stocks are not a successful short-term investment since they are vulnerable to non-sharia-compliant transaction. As a consequence, Islamic stocks are an investment instrument whose primary aim is to invest in assisting a company's operations so that investors can benefit from the company's profits. Regarding an overreaction phenomenon in the Islamic stock market in Indonesia, the findings are in line with previous research (Fatima et al., 2019; Mujadiddah et al., 2020; Musnadi et al., 2018; Tanjung \& Siregar, 2018). Similarly, the empirical findings also confirm the previous findings about the existence of anomalies in the Indonesian 
stock market (Andriansyah, 2017; Faisal \& Majid, 2016; Octavio \& Lantara, 2014; Sumiyana, 2009).

The outcomes indicate that COVID-19 does not only affect the health sector, but also Indonesia's economy and finance. This crisis generates a large response from investors, especially foreign investors, to the Islamic stock market. Related to COVID-19 information, sharia stock price movements experience a sharp decline and high volatility. Various policies issued by the government in dealing with the impact of COVID-19 have slowly brought the value of the Islamic stock index recover to its starting point and becoming more stable as it was before the COVID-19.

\section{CONCLUSIONS}

The overreaction hypothesis testing conducted in the research reveals that the Islamic stock market in Indonesia remains inefficient as evidenced by the overreaction occurring in several events related to COVID-19. This phenomenon is proven by a several test on the difference in the average abnormal return value of winner and loser stocks before and after the event. An overreaction is triggered by a sequence of four occurrences. The announcement of COVID-19 transmission and lockdown (Event 2) leads to an overreaction in winner stocks. Furthermore, the overreaction phenomenon of loser stock is caused by the announcement of the United States fiscal stimulus (Event 5) and the announcement of the PSBB (Event 6). Meanwhile, the announcement of New Normal (Event 7) causes Islamic stocks, both winner and loser experiencing an overreaction. In addition, the results have found that the COVD-19 pandemic has a significant impact on the Jakarta Islamic Index (JII) and several stock sectors consisting of mining; property, real estate, and building construction; infrastructure, utilities and transportation; and trade, services and investment.

Regression analysis is employed to determine the influencing factors of overreaction phenomenon. Furthermore, the regression model evaluation only shows the announcement of the COVID-19 transmission and lockdown (Event 2) which could be explained through the estimation of the regression model. The regression results in Event 2 indicate that the independent variables in the research model jointly influence the overreaction phenomenon as shown by the significant F-stat value. Overall, based on the t-stat value, it appears that the variables of company leverage (Lev) and market capitalization (Ln MCap) have negative effects on overreaction, whereas the variable trading volume (LTV) has a positive effect on overreaction.

The overreaction phenomenon is one of the causes of market inefficiency. This was explained in the Fatwa DSN MUI Number 80 of 2011 with the existence of insider trading transactions or misleading information on the overreaction phenomenon which caused prices to be unnatural and the market became inefficient. As a result, investors must pay attention to these indicators to prevent overreaction and avoid suffering a significant loss due to extreme prices. In addition, investors should pay attention to transactions in accordance with Islamic principles as the research finds that there are still speculative transactions, especially for factors which lead to the overreaction phenomenon. As a consequence, more Islamic market investors need to be educated in order to conduct stock transactions in accordance with Islamic Principles. The research scope is limited to seven incidents over a brief period of time. Therefore, further research is required to inspect how Islamic stock markets react to other events in Indonesia, as it is likely to be an overreaction phenomenon in the longer term.

\section{REFERENCES}

Ali, R., Ahmad, Z., \& Anusakumar, S. V. (2012). Stock market overreaction and trading volume: Evidence from Malaysia. Asian Academy of Management Journal of Accounting and Finance, 7(2), 103-119.

Andriansyah, A. (2017). The real effects of primary and secondary equity markets on firm performance: Evidence from Indonesia. International Journal of Managerial Finance, 13(4), 397-418. https://doi. org/10.1108/IJMF-01-2017-0006

Boubaker, S., Farag, H., \& Nguyen, D. K. (2015). Shortterm overreaction to specific events: Evidence from an emerging market. Research in International Business and Finance, 35, 153-165. https://doi. org/10.1016/j.ribaf.2014.10.002

De Bondt, W. F. M. \& Thaler, R. (1985). American Finance Association does the stock market overreact? The Journal of Finance, 40(3), 793-805. https://doi. org/10.1111/j.1540-6261.1985.tb05004.x

Faisal \& Majid, M. S. A. (2016). Re-examination of calendar anomalies in the Indonesian stock market. Journal of Applied Economic Sciences, 11(8), 1714-1723.

Fama, E. F. (1970). Efficient capital markets: A review of theory and empirical work. The Journal of Finance, 25(2), 383-417. https://doi.org/10.2307/2325486

Farag, H. \& Cressy, R. (2010). Do unobservable factors explain the disposition effect in emerging stock markets? Applied FinancialEconomics, 20(15), 11731183. https://doi.org/10.1080/09603101003781463

Fatima, A., Rashid, A., \& Khan, A. -uz Z. (2019). Asymmetric impact of shocks on Islamic stock indices: a cross country analysis. Journal of Islamic Marketing, 10(1), 2-86. https://doi.org/10.1108/ JIMA-04-2017-0043

Fauzi, R. \& Wahyudi, I. (2016). The effect of firm and stock characteristics on stock returns: Stock market crash analysis. Journal of Finance and Data Science, 2(2), 112-124. https://doi.org/10.1016/j.jfds.2016.07.001

Hassan, S. M. \& Gavilanes, J. M. R. (2021). First to react is the last to forgive: Evidence from the stock market impact of COVID 19. Journal of Risk and Financial Management, 14(1), 26. https://doi.org/10.3390/ jrfm14010026 
Hatem, B. S. (2015). What determines cumulative abnormal returns? An empirical validation in the French market. International Business Research, 8(12), 89. https://doi.org/10.5539/ibr.v8n12p89

Ibrahim, I., Kamaludin, K., \& Sundarasen, S. (2020). COVID-19, government response, and market volatility: Evidence from the Asia-Pacific developed and developing markets. Economies, 8(4), 105. https://doi.org/10.3390/economies 8040105

Lerskullawat, P. \& Ungphakorn, T. (2019). Does overreaction still exist in Thailand? Kasetsart Journal of Social Sciences, 40(3), 689-694. https://doi.org/10.1016/j. kjss.2018.02.001

Liu, H., Manzoor, A., Wang, C., Zhang, L., \& Manzoor, Z. (2020). The COVID-19 outbreak and affected countries stock markets response. International Journal of Environmental Research and Public Health, 17(8), 1-19. https://doi.org/10.3390/ ijerph17082800

Lobe, S. \& Rieks, J. (2011). Short-term market overreaction on the Frankfurt stock exchange. Quarterly Review of Economics and Finance, 51(2), 113-123. https:// doi.org/10.1016/j.qref.2010.12.002

Mujadiddah, S., Achsani, N. A., \& Irfany, M. I. (2020). Short-term overreaction of Islamic stocks to specific events in Indonesia. Journal of Islamic Monetary Economics and Finance, 6(1), 117-134. https://doi. org/10.21098/jimf.v6i1.1121

Musnadi, S., Faisal, \& Majid, M. S. A. (2018). Overreaction and underreaction anomalies in the Indonesian stock market: A sectoral analysis. International Journal of Ethics and Systems, 34, 442-457. https://doi. org/10.1108/IJOES-12-2017-0235

Octavio, D. Q. \& Lantara, I. W. N. (2014). Market overreaction, size effect atau liquidity effect? Studi pada Bursa Efek Indonesia. Jurnal Manajemen, Strategi Bisnis dan Kewirausahaan, 8(1), 1117. https://ojs.unud.ac.id/index.php/jmbk/article/ view/8052

Siddiqui, T. A., Ahmed, H., \& Naushad, M. (2020). Diffusion of COVID-19 impact across selected stock markets: A wavelet coherency analysis. Investment Management and Financial Innovations, 17(4), 202214. https://doi.org/10.21511/imfi.17(4).2020.19

Sohail, A., Rehman, M. U. R., \& Javid, A. Y. (2017). Stock market reactions on returns and trading volume: The impact of the global financial crisis. Revista Evidenciação Contábil \& Finanças, 5(1), 132-151. https://doi.org/10.18405/recfin20170108

Sumiyana, S. (2009). The behavior of opening and closing prices noise and overreaction. Gadjah Mada International Journal of Business, 11(1), 73. https:// doi.org/10.22146/gamaijb.5542

Tanjung, H. \& Siregar, T. A.M. (2018). Analisis votalitas saham di Jakarta Islamic Index (JII) periode Januari 2015-Januari 2018. Ihtifaz: Journal of Islamic Economics, Finance, and Banking, 1(1), 147. https:// doi.org/10.12928/ijiefb.v1i1.270

Yan, C. (2020). COVID-19 outbreak and stock prices: Evidence from China. SSRN Electronic Journal. https://doi.org/10.2139/ssrn.3574374

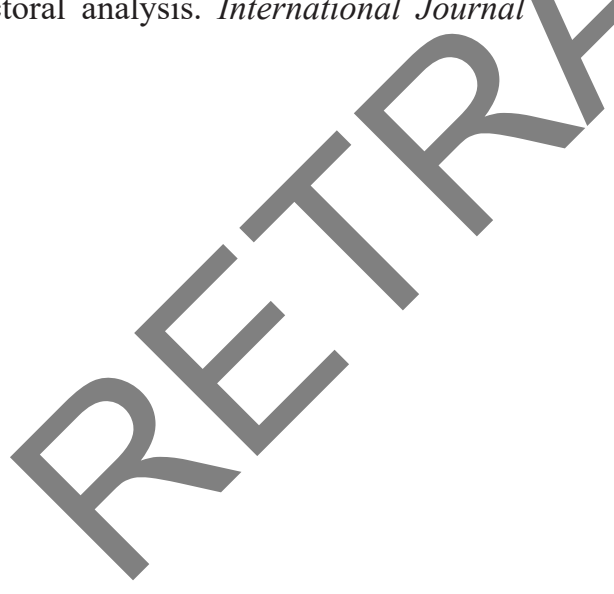

